\title{
Anopheles arabiensis seasonal densities and infection rates in relation to landscape classes and climatic parameters in a Sahelian area of Senegal
}

El Hadji Malick Ngom ${ }^{1,2}$, Ndèye Diango Faye ${ }^{2}$, Cheikh Talla1,3, El Hadji Ndiaye ${ }^{1,2}$, Jacques-André Ndione ${ }^{4}$, Ousmane Faye ${ }^{2}$, Yamar Ba ${ }^{1}$, Mawlouth Diallo ${ }^{1}$ and Ibrahima Dia ${ }^{1 *}$

\begin{abstract}
Background: The influence of environmental and climatic factors on malaria vector bionomics and transmission is an important topic in the context of climatic change particularly at macro-geographical level. Sahelian areas could be particularly affected due to heterogeneous features including high inter-annual variability in rainfall and others associated parameters. Therefore, baseline information on the impact of environmental and climatic factors on malaria transmission at micro-geographical level is required for vector risk management and implementation of control strategies.

Methods: Malaria vectors were collected indoors by pyrethrum spray catches in 14 villages belonging to 4 different landscape classes (wooded savanna, shrubby savanna, bare soils and steppe) in the sylvo-pastoral area of Senegal. Plasmodium falciparum infection rates were determined using an indirect enzyme-linked immunosorbent assay (ELISA).

Results: An. arabiensis was the predominant species in all landscape classes and was the only species collected at the end of the rainy season excepted in villages located in bare soils where it cohabited with An. coluzzii. Mean temperature and relative humidity showed similar variations in all the landscape classes covered whereas rainfall was more heterogeneous in terms of pattern, frequency and amount. The mean densities of An. arabiensis displayed high seasonal differences with peaks observed in August or September. A positive non-significant correlation was observed between An. arabiensis densities for rainfall and humidity whereas a negative non-significant correlation was reported for temperature. Plasmodium falciparum-infected mosquitoes were detected only in wooded savanna and bare soils villages.
\end{abstract}

Conclusions: These observations suggest key roles played by landscape classes and rainfall in malaria vector densities, infection rates and malaria transmission that could be more pronounced in villages situated in wooded savanna and bare soils. Due to the close relationship between environmental and meteorological parameters in this Sahelian region, additional studies on the impact of these parameters are required to further ascertain their association with entomological parameters involved in malaria transmission. From the public health point of view, such information could be useful for human population settlements as well as for monitoring and modelling purposes giving early warning system for implementation of interventions in these unstable transmission zones.

Keywords: Anopheles arabiensis, Sahelian area, Landscape classes, Climatic parameters, Malaria transmission

\footnotetext{
*Correspondence: dia@pasteur.sn

'Unité d'entomologie médicale, Institut Pasteur de Dakar, 36 Avenue Pasteur, BP 220 Dakar, Senegal

Full list of author information is available at the end of the article
}

\section{Biomed Central}

(c) 2014 Ngom et al.; licensee BioMed Central. This is an Open Access article distributed under the terms of the Creative Commons Attribution License (http://creativecommons.org/licenses/by/4.0), which permits unrestricted use, distribution, and reproduction in any medium, provided the original work is properly credited. The Creative Commons Public Domain Dedication waiver (http://creativecommons.org/publicdomain/zero/1.0/) applies to the data made available in this article unless otherwise stated. 


\section{Background}

Many vector-borne diseases occur in tropical and subtropical areas where climatic and environmental conditions are favourable for their propagation [1]. The recent observations on climatic changes worldwide are causing panic and their impact on these diseases are still not well established. Many studies suggest that climate change would lead to a resurgence of vector-borne diseases like malaria $[2,3]$ and it is well known that malaria transmission and prevalence could be highly influenced by spatial and temporal changes in the environment [4]. This is particularly important in non-endemic areas characterised by a low level of malaria transmission and a high variability of climatic and environmental parameters, where a comeback or resurgence of malaria with a high risk of morbidity and mortality in all age groups is expected. For instance, recent studies conducted in western Kenya highlands have suggested an increase of malaria epidemics attributed to changes in land cover $[5,6]$. Similar observations are expected in the Sahel (southern edge of the Saharan desert) characterized by heterogeneous features including high inter-annual variability in rainfall [7]. The human populations of this rural area are mainly peasant farmers who depend on seasonal rainfall for agriculture and livestock rearing to generate food and financial gains. On the other hand, water and pastural availability determine human settlements with a direct impact on land cover and use.

While the impact of land use or agricultural practices on malaria vectors occurrence and distribution at macrogeographical levels has been addressed in many situations $[8,9]$, there is very scarce data at micro-geographical levels. Recent findings indicate that small-scale differences within an area may have important consequences $[10,11]$ on malaria epidemiology. Krefis et al. [12] showed a direct link of an increase or decrease of malaria risk depending on the types of land cover. For malaria vectors, few studies were carried out on the correlation between environmental parameters such as land cover or use and adults stages of malaria vectors contrary to the aquatic stages $[13,14]$. However, as adult vector abundance is positively associated with the availability of aquatic habitats $[15,16]$, results on land cover changes on aquatic stages are usually extrapolated to estimate adult vector densities.

In the present study, we examined the influence of different landscape classes on malaria vector abundance and infection rates in a Sahelian area of Senegal characterised naturally by a low level of malaria transmission, high interannual variability of climate changes [17] and high morbidity rates during seasons with heavy rainfall [18]. This information is important for the understanding of environmental determinants of malaria transmission heterogeneity at a micro-geographical level to assess vector pressure, risk management and implementation of control strategies.

\section{Methods}

\section{Description of the study area}

The current study was conducted in 14 villages situated around the village of Barkedji (14 ${ }^{\circ} 52^{\prime} 04 \mathrm{~W}-15^{\circ} 16^{\prime} 42 \mathrm{~N}$ ) in the Sylvo-pastoral area of Senegal (Figure 1) from July to November 2009. The climate is typically Sahelian and is characterized by a semi-arid climate with a summer monsoon (the rainy season) that lasts from July to midOctober. The mean annual temperature is $28.8^{\circ} \mathrm{C}$ with the lowest value $\left(24.4^{\circ} \mathrm{C}\right)$ recorded in January and the highest $\left(35.5^{\circ} \mathrm{C}\right)$ in May. The study area is characterized by a complex and dense network of ponds located within the fossil Ferlo riverbed that are filled with water during the rainy season but which dry out during the rest of the year (Figure 1). It is characterized by the predominance of sandy-loam soils on which grows a grass cover dominated by shrubs represented mostly by thorny bushes. The population of this area is estimated at 14,200 inhabitants comprising of Fulani (85\%), Wolof (12\%), Moors and Serer (3\%). Human activities are dominated by livestock rearing (mainly cattle, sheep, goats) and agriculture (mainly millet).

No specific permission was required for work in each of the selected villages. After explaining the purpose of this study, verbal consent was obtained from the village chief as well as from heads of households. Vector control measures used in the study area include personal protections and use of long-lasting insecticidal nets (LLINs) at community level.

\section{Weather and environmental data collection}

Climatic data were collected using weather stations (Campbell scientific BW200) installed near the villages of Barkedji, Keur Alpha, Keur Aliou and Keur Diallo (Figure 1).

The landscape class was chosen as environmental parameter. Landscape classes were defined using remote sensing and geospatial analyses from a SPOT 5 satellite image based on the description of the vegetation classes according to the combination of the FAO and CSA systems $[19,20]$. All 14 sampling sites were geo-referenced with a hand-held GPS receiver and each of them was classified to the corresponding landscape class. Four landscape classes were identified in the study area. Table 1 and Figure 1 present each of the 14 villages and the corresponding landscape type.

\section{Mosquitoes sampling and processing}

Daytime indoor resting mosquitoes were collected monthly within the same selected houses from all 14 villages by pyrethrum spray catches (PSC). Upon collection, Anopheles females were sorted and identified to species using the morphological key of Gillies and De Meillon [21]. For the known malaria vectors already described in the study area, 


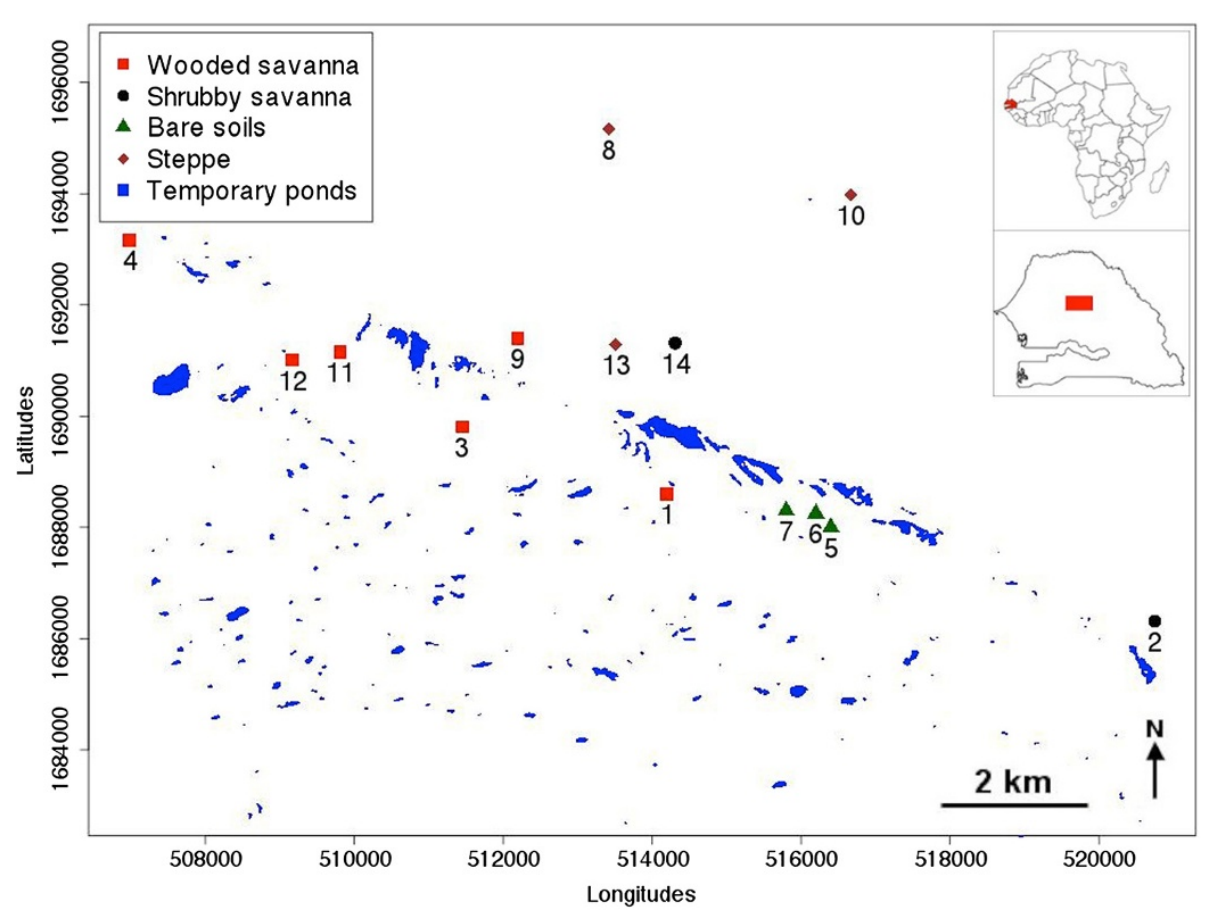

Figure 1 Localisation of the study sites. Numbers indicate the sites ID presented in Table 1. Data points are projected in the UTM zone 28 N. Weather stations were installed in Barkedji (ID:1), Keur Alpha (2), Keur Aliou (6) and Keur Diallo (10).

the physiological status was recorded, then all mosquitoes were stored individually in labelled vials containing silica gel for subsequent analyses. In the laboratory, the mosquitoes from the Anopheles gambiae complex were identified using the molecular method of Fanello et al. [22]. The

Table 1 Main characteristics of studied villages

\begin{tabular}{lllll}
\hline Sites ID & Villages & Longitudes & Latitudes & $\begin{array}{l}\text { Landscape } \\
\text { classes }\end{array}$ \\
\hline 1 & Barkedji & $15^{\circ} 17^{\prime} 0^{\prime \prime} \mathrm{N}$ & $14^{\circ} 53^{\prime} \mathrm{O}^{\prime \prime} \mathrm{W}$ & Wooded savanna \\
2 & Keur Alpha & $15^{\circ} 14^{\prime} 42^{\prime \prime} \mathrm{N}$ & $14^{\circ} 47^{\prime} 57^{\prime \prime} \mathrm{W}$ & Shrubby savanna \\
3 & Dague Nabe & $15^{\circ} 17^{\prime} 04^{\prime \prime} \mathrm{N}$ & $14^{\circ} 52^{\prime} 96^{\prime \prime} \mathrm{W}$ & Wooded savanna \\
4 & Diabal & $15^{\circ} 18^{\prime} 53^{\prime \prime} \mathrm{N}$ & $14^{\circ} 56^{\prime} 05^{\prime \prime} \mathrm{W}$ & Wooded savanna \\
5 & Keur Dadal & $15^{\circ} 16^{\prime} 23^{\prime \prime} \mathrm{N}$ & $14^{\circ} 51^{\prime} 6^{\prime \prime} \mathrm{W}$ & Bare soils \\
6 & Keur Aliou & $15^{\circ} 15^{\prime} 86^{\prime \prime} \mathrm{N}$ & $14^{\circ} 50^{\prime} 30^{\prime \prime} \mathrm{W}$ & Bare soils \\
7 & Keur Gallo & $15^{\circ} 16^{\prime} 25^{\prime \prime} \mathrm{N}$ & $14^{\circ} 51^{\prime} 01^{\prime \prime} \mathrm{W}$ & Bare soils \\
8 & Keur Bandji & $15^{\circ} 19^{\prime} 34^{\prime \prime} \mathrm{N}$ & $14^{\circ} 52^{\prime} 20^{\prime \prime} \mathrm{W}$ & Steppe \\
9 & Keur Bathiel & $15^{\circ} 17^{\prime} 32^{\prime \prime} \mathrm{N}$ & $14^{\circ} 52^{\prime} 43^{\prime \prime} \mathrm{W}$ & Wooded savanna \\
10 & Keur Diallo & $15^{\circ} 19^{\prime} 10^{\prime \prime} \mathrm{N}$ & $14^{\circ} 50^{\prime} 24^{\prime \prime} \mathrm{W}$ & Steppe \\
11 & Niakha & $15^{\circ} 17^{\prime} 28^{\prime \prime} \mathrm{N}$ & $15^{\circ} 54^{\prime} 18^{\prime \prime} \mathrm{W}$ Wooded savanna \\
12 & Niakha Ndiaybe & $15^{\circ} 15^{\prime} 56^{\prime \prime} \mathrm{N}$ & $14^{\circ} 50^{\prime} 18^{\prime \prime} \mathrm{W}$ & Wooded savanna \\
13 & Keur Daha & $15^{\circ} 17^{\prime} 31^{\prime \prime} \mathrm{N}$ & $14^{\circ} 52^{\prime} 17^{\prime \prime} \mathrm{W}$ & Steppe \\
14 & Wouro Thilli & $15^{\circ} 17^{\prime} 31^{\prime \prime} \mathrm{N}$ & $14^{\circ} 51^{\prime} 36^{\prime \prime} \mathrm{W}$ & Shrubby savanna \\
\hline
\end{tabular}

heads and thoraces of all anopheline females were tested by ELISA for the detection of Plasmodium falciparum circumsporozoite protein (CSP) using the procedure of Wirtz et al. [23].

\section{Data analysis}

To study the association between landscape classes and entomological parameters (densities, infection rates), each of the 14 villages was classified to the corresponding landscape class. For analysis of the distribution between landscape classes', monthly anopheline females' densities were calculated as the number of specimens per room (SPR) and $\log$ transformed to normalize the distribution. The Shapiro-Wilk test was used to test the normality of the data and Levene's test for equality of variances. Subsequently, the differences between landscape classes, mean densities and collection months were analysed using analysis of variance (ANOVA) followed by Tukey-Kramer post-hoc tests. The circum-sporozoite protein infection rates (CSP-IR) was calculated as the proportion of females found to contain the CS protein. To study the associations between the temporal distribution of the vector densities and rainfall, mean relative humidity and temperature, the data from four villages representative of the 4 landcape classes were pooled and the associations evaluated by the Pearson correlation. All these analyses were performed using the R software (version 2.14.1). 


\section{Results}

\section{Mosquito collection}

A total of 7652 Anopheles specimens belonging to 6 species were collected by PSC from the four landscape classes (Table 2). An. gambiae s.l. was the predominant species in all landscape classes. An. rufipes was also collected in all landscape classes but was more frequent in villages located in wooded and shrubby savanna. An. funestus, An. pharoensis and $A n$. domicola were collected only in wooded savanna villages whereas $A n$. welcomei was scarce and observed in bare soils villages.

\section{Distribution pattern of An. gambiae complex within the study area}

Overall, 863 specimens belonging to the $A n$. gambiae complex were molecularly identified. Only $A n$. arabiensis and $A n$. coluzzii were present in the study area; $A n$. arabiensis was the most predominant species with $81.8 \%$ $(706 / 863)$ in the collection. No statistically significant difference was observed in the proportions of $A n$. arabiensis in the different landscape classes $\left(\chi^{2}=4.45, \mathrm{df}=3\right.$, $\mathrm{p}=0.22$ ). The relative proportions of the two species fluctuated based on the landscape class and month of collection.

An. arabiensis was the most abundant species in wooded and shrubby savanna villages at any time point during the months of collections and moreover, it was the only species collected at the end of the rainy season in November (Table 3 and Additional file 1). An. coluzzii on the other hand was absent or had very low proportions at the beginning of the rainy season in July (see Additional file 2). Its abundances increased gradually reaching maximum levels in August or September before it started to decline steadily. In shrubby savanna villages $A n$. coluzzii was collected only in August and September with the respective frequencies of 42.9\% and 11.1\% (Table 3 and Additional file 2).

In bare soils and steppe landscapes, the two species were collected almost throughout the whole collection period (4 out of the 5 months collection period). The lowest frequencies of $A n$. arabiensis were observed in August and September respectively (Table 3 and Additional file 2).

\section{Monthly densities of Anopheles gambiae mosquitoes}

Overall, 2695 rooms were sprayed during the surveys carried out resulting in the collection of $6886 \mathrm{An}$. gambiae mosquitoes. Overall, the mean number of specimens per room (SPR) was estimated to be 3.5. The means for the villages situated in the different landscapes (wooded savanna, shrubby savanna, bare soils and steppe) were $3 \pm 0.45,3.79 \pm 2.32,3.87 \pm 0.84,3.94 \pm$ 1.25 respectively. These means were statistically comparable $(\mathrm{F}=0.26, \mathrm{p}=0.85)$. However, statistically significant differences were observed between the monthly means

Table 2 Number and abundance (\%) of anopheline species collected in each of the four landscape classes

\begin{tabular}{|c|c|c|c|c|c|c|c|c|c|c|c|c|}
\hline \multirow{2}{*}{$\begin{array}{l}\text { Landscape classes/ } \\
\text { villages }\end{array}$} & \multicolumn{2}{|c|}{ An. funestus } & \multicolumn{2}{|c|}{ An. gambiae } & \multicolumn{2}{|c|}{ An. pharoensis } & \multicolumn{2}{|c|}{ An. rufipes } & \multicolumn{2}{|c|}{ An. welcomei } & \multicolumn{2}{|c|}{ An. domicola } \\
\hline & $\mathrm{N}$ & $\%$ & $\mathbf{N}$ & $\%$ & $\mathbf{N}$ & $\%$ & $\mathrm{~N}$ & $\%$ & $\mathbf{N}$ & $\%$ & $\mathbf{N}$ & $\%$ \\
\hline \multicolumn{13}{|l|}{ Wooded savanna } \\
\hline Barkedji & 4 & 0.10 & 3670 & 90.82 & 5 & 0.12 & 362 & 8.96 & 0 & 0.00 & 0 & 0.00 \\
\hline Dague Nabe & 1 & 0.24 & 404 & 95.28 & 0 & 0.00 & 18 & 4.25 & 0 & 0.00 & 1 & 0.24 \\
\hline Diabal & 1 & 0.13 & 681 & 91.53 & 0 & 0.00 & 62 & 8.33 & 0 & 0.00 & 0 & 0.00 \\
\hline Keur Bathiel & 0 & 0.00 & 42 & 85.71 & 0 & 0.00 & 7 & 14.29 & 0 & 0.00 & 0 & 0.00 \\
\hline Niakha & 1 & 0.12 & 717 & 82.99 & 1 & 0.12 & 145 & 16.78 & 0 & 0.00 & 0 & 0.00 \\
\hline Niakha Ndiaybe & 1 & 0.14 & 602 & 83.15 & 0 & 0.00 & 121 & 16.71 & 0 & 0.00 & 0 & 0.00 \\
\hline \multicolumn{13}{|l|}{ Shrubby savanna } \\
\hline Keur Alpha & 0 & 0.00 & 139 & 96.53 & 0 & 0.00 & 5 & 3.47 & 0 & 0.00 & 0 & 0.00 \\
\hline Wouro Thilli & 0 & 0.00 & 28 & 90.32 & 0 & 0.00 & 3 & 9.68 & 0 & 0.00 & 0 & 0.00 \\
\hline \multicolumn{13}{|l|}{ Bare soils } \\
\hline Keur Dadal & 0 & 0.00 & 231 & 94.67 & 0 & 0.00 & 13 & 5.33 & 0 & 0.00 & 0 & 0.00 \\
\hline Keur Aliou & 0 & 0.00 & 55 & 93.22 & 0 & 0.00 & 4 & 6.78 & 0 & 0.00 & 0 & 0.00 \\
\hline Keur Gallo & 0 & 0.00 & 85 & 93.41 & 0 & 0.00 & 5 & 5.49 & 1 & 1.10 & 0 & 0.00 \\
\hline \multicolumn{13}{|l|}{ Steppe } \\
\hline Keur Bandji & 0 & 0.00 & 142 & 98.61 & 0 & 0.00 & 2 & 1.39 & 0 & 0.00 & 0 & 0.00 \\
\hline Keur Daha & 0 & 0.00 & 46 & 97.87 & 0 & 0.00 & 1 & 2.13 & 0 & 0.00 & 0 & 0.00 \\
\hline Keur Diallo & 0 & 0.00 & 44 & 95.65 & 0 & 0.00 & 2 & 4.35 & 0 & 0.00 & 0 & 0.00 \\
\hline Total & 8 & 0.10 & 6886 & 89.99 & 6 & 0.08 & 750 & 9.80 & 1 & 0.01 & 1 & 0.01 \\
\hline
\end{tabular}

$\mathrm{N}=$ number, $\%=$ percentage. 
Table 3 Monthly variations of An. arabiensis mean proportions ( \pm se) in each of the four landscape classes

\begin{tabular}{llllll}
\hline Landscape classes & \multicolumn{3}{l}{ Study period } & & \\
\cline { 2 - 6 } & July & August & September & October & November \\
\hline Wooded savanna & $89.9 \pm 3.4^{\mathrm{b}}$ & $59 \pm 12.1^{\mathrm{a}}$ & $88.8 \pm 5.1^{\mathrm{b}}$ & $98 \pm 2^{\mathrm{b}}$ & $100^{\mathrm{b}}$ \\
Shrubby savanna & $100^{\mathrm{c}}$ & $57.1^{\mathrm{a}}$ & $88.7 \pm 1.3^{\mathrm{b}}$ & $100^{\mathrm{c}}$ & $100^{\mathrm{c}}$ \\
Bare soils & - & $72.7 \pm 13.8^{\mathrm{a}}$ & $92.5 \pm 3.8^{\mathrm{a}}$ & $93.3 \pm 6.7^{\mathrm{a}}$ & $90 \pm 10^{\mathrm{a}}$ \\
Steppe & $75 \pm 25^{\mathrm{a}, \mathrm{b}}$ & $65.3 \pm 1.4^{\mathrm{a}, \mathrm{b}}$ & $53.3 \pm 13.3^{\mathrm{a}}$ & $66.7 \pm 33.3^{\mathrm{a}}$ & $100^{\mathrm{b}}$ \\
\hline
\end{tabular}

For the different landscape classes, means with different letters are significantly different $(p<0.05)$.

Comparisons were made between months for each of the four landscape classes. Standard errors not presented are null.

in wooded savanna and bare soils villages (Figure 2). Overall, the mean densities were low at the beginning of the surveys in July (beginning of rainy season) with a maximum of 1 SPR in all landscape classes. They increased steadily thereafter reaching a peak in September for shrubby savanna villages, bare soils and steppe whilst for wooded savanna villages the peak was observed in October (Figure 2).

\section{Influence of climate parameters on Anopheles densities}

This influence was studied in 4 sites representing each of the four landscape classes: Barkedji (wooded savanna),
Keur Alpha (shrubby savanna), Keur Aliou (Bare soils) and Keur Diallo (Steppe). In each of these sites, the mean temperature and mean relative humidity showed similar variations whereas the rainfall was heterogeneous in terms of patterns, frequency and quantity. Rainfall peaked in September in Barkedji village and in the three other villages it peaked in August (Figure 3). The highest number of SPR was observed soon after the rainfall peaked either in October and September in Barkedji or September and August for the three other villages. A positive but not significant correlation was observed with rainfall (Pearson $\mathrm{r}=0.09, \mathrm{p}=0.71$ ) and humidity

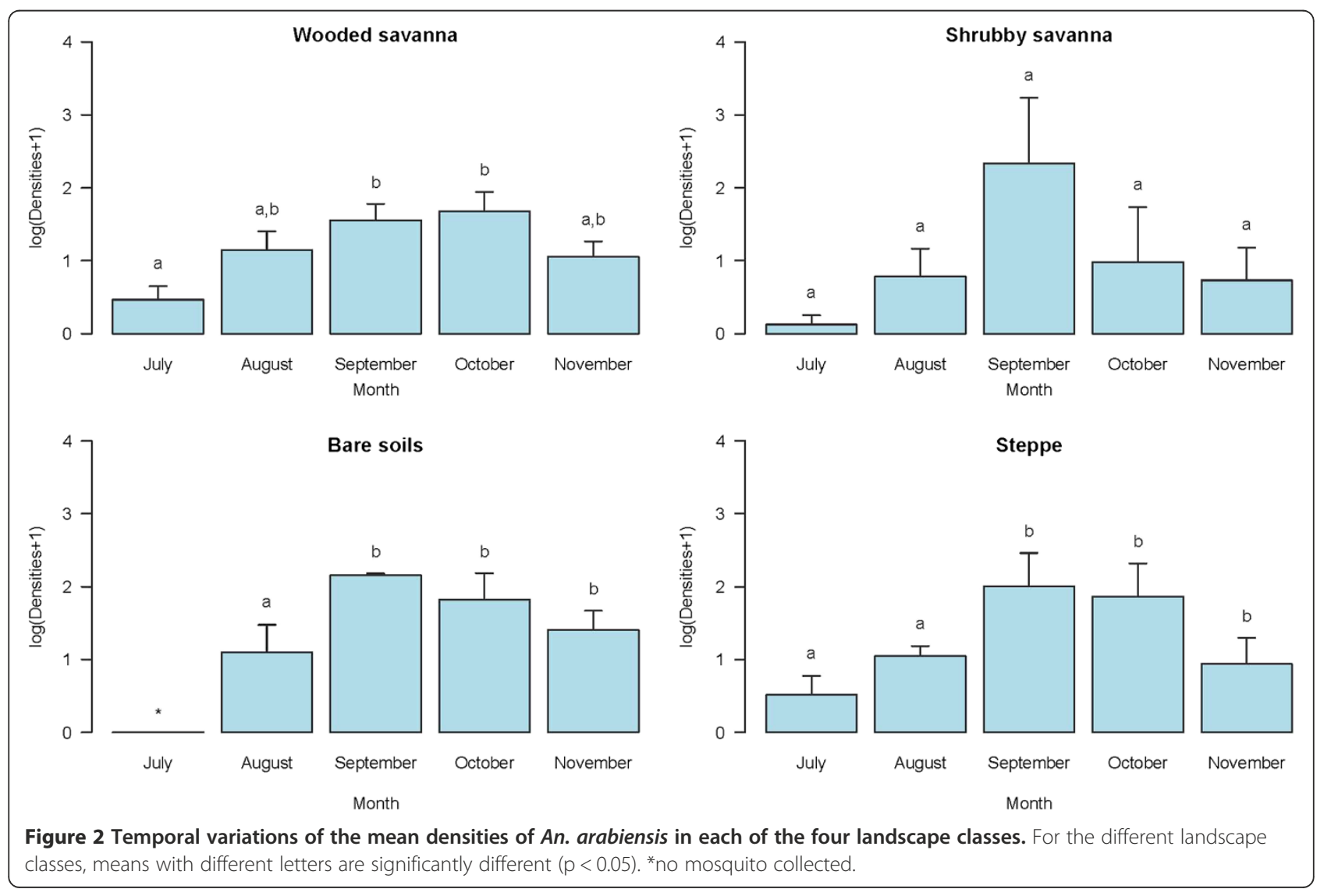




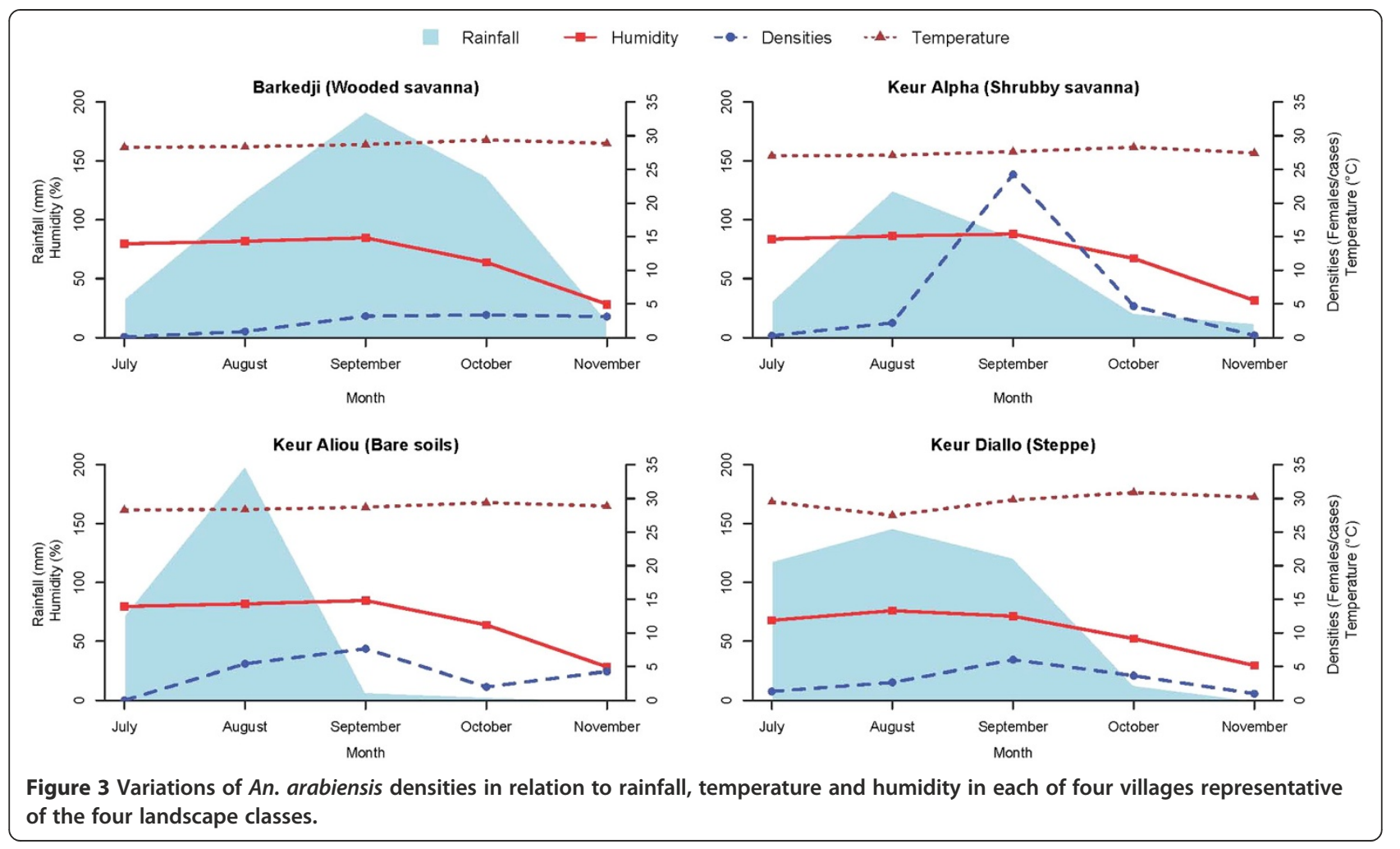

(Pearson $\mathrm{r}=0.25, \mathrm{p}=0.29$ ) while a negative non-significant correlation was observed for temperature (Pearson $r=-0.09$, $\mathrm{p}=0.68)$ (see Additional file 3).

\section{Circumsporozoite infection rates}

The head and thoraces of 3768 An. gambiae s.l. females were tested by ELISA for Plasmodium falciparum CS antigen detection (Table 4). No specimen collected from villages situated in shrubby savanna and steppe were CS positive. Overall 11 positive females were detected, 10 in villages situated in wooded savanna (6 collected in Barkedji in August, 2 in Niakha in September and 2 in Niakha Ndiaybe in September) and 1 in a village within bare soils (Keur Aliou in August). The mean infection rates were $0.34 \%$ in wooded savanna and $0.37 \%$ in bare soils, respectively. No statistically significant difference was observed between the four landscape classes $\left(\chi^{2}=0.84\right.$, $\mathrm{df}=3, \mathrm{p}=0.84)$. A similar result was observed between wooded savanna villages $\left(\chi^{2}=2.49, \quad \mathrm{df}=5, \mathrm{p}=0.78\right)$ whereas the infection rates were significantly different between bare soils villages $\left(\chi^{2}=13.94, \mathrm{df}=2, \mathrm{p}<0.001\right)$.

\section{Discussion}

All the anopheline species collected during this study were already described in the area [24]. However, the list is not exhaustive since other known species in the area were not collected even though the study was conducted longitudinally. This is due primarily to the collection
Table 4 An. arabiensis mean infection rates calculated by enzyme-linked immunosorbent assay for $P$. falciparum in the different villages/lansdcape classes

\begin{tabular}{llllll}
\hline Villages & Negative & Positive & Total & CSP-IR (\%) & 95\% Cl \\
\hline Wooded savanna & & & & & \\
Barkedji & 1705 & 6 & 1711 & 0.35 & $0.16-0.76$ \\
Dague Nabe & 227 & 0 & 227 & 0 & - \\
Diabal & 301 & 0 & 301 & 0 & - \\
Keur Bathiel & 29 & 0 & 29 & 0 & - \\
Niakha & 606 & 2 & 608 & 0.33 & $0.09-1.19$ \\
Niakha Ndiaybe & 367 & 2 & 369 & 0.54 & $0.15-1.95$ \\
Shrubby savanna & & & & & \\
Keur Alpha & 110 & 0 & 110 & 0 & - \\
Wouro Thilli & 18 & 0 & 18 & 0 & - \\
Bare soils & & & & & \\
Keur Dadal & 195 & 0 & 195 & 0 & - \\
Keur Aliou & 17 & 1 & 18 & 5.55 & $0.28-25.76$ \\
Keur Gallo & 55 & 0 & 55 & 0 & - \\
Steppe & & & & & - \\
Keur Bandji & 80 & 0 & 80 & 0 & - \\
Keur Daha & 17 & 0 & 17 & 0 & - \\
Keur Diallo & 30 & 0 & 30 & 0 & - \\
Total & 3757 & 11 & 3768 & 0.29 & $0.16-0.52$ \\
\hline
\end{tabular}

CSP-IR = Circumsporozoite protein infection rate, $\mathrm{Cl}=$ confidence interval based on a binomial distribution. 
method used that may have targeted endophilic species closely associated with human environments.

$A n$. arabiensis was the most common species during this study. An. pharoensis and An. funestus, also vectors of malaria in Senegal were present but at very low proportions. An. pharoensis was previously described in the area [25] whereas An. funestus was never observed during previous malaria vector studies conducted in the area $[17,26]$. The presence of An. funestus therefore confirms the comeback of this species in the Senegal River basin which was described in a recent study [27]. This species was first described in the Senegal River basin in the 1970s, but thereafter it disappeared following recurrent droughts only to appear again in 1999 in the low valley of the Senegal River [28]. Its presence in the current study area extends the re-colonization zone to the Ferlo area. This is perhaps due to the restoration and presence of its breeding sites that consist of natural/ artificial permanent and semi-permanent water bodies with floating or emerging vegetation. This study area has characteristic favourable breeding sites of this nature constituting temporary pools covered with vegetation emerging from the middle to the end of the rainy season [29].

The presence of An. funestus was limited to wooded savanna villages only and at low proportions $(0.01 \%)$. Therefore, its involvement in malaria transmission is presumed to be low. Like An. arabiensis, An. rufipes was also observed in all landscape types. Due to the relatively high proportions observed for An. rufipes, the determination of the role of this species in malaria transmission needs further investigation to incriminate it, as a recent study conducted in Burkina Faso has demonstrated its involvement in the transmission of human Plasmodium [30].

The variations observed in the proportions of the species of the An. gambiae complex in the four different landscape classes, could express different adaptive characteristics of these species. An. arabiensis was found to be the prevalent species in the whole study area. This observation is in agreement with the distribution of this species, which is located in dry to humid savannah areas [31]. Moreover, it is noteworthy that the highest proportions of this species were observed during the less humid months namely in July and November.

Despite the comparable mean densities observed in the four landscape classes, significant variations were observed when considering the collection months in villages located in wooded savanna and bare soils. Malaria transmission could be higher in these villages during September and October because the highest densities and infected mosquitoes with $P$. falciparum were observed in this period. Additional evidence comes from a recent study conducted in the study area on the spatiotemporal analysis of feeding behaviour [32], which showed that it was mainly during the rainy season that the blood meals taken from human were widespread and homogenously distributed in the study area. The anthropophilic rates were higher in September in villages situated in wooded savanna whereas in bare soils villages, the differences were less marked but the blood meals taken from humans were more uniformly distributed in September. The results of Lemasson et al. [17] is also an evidence to indicate maximal transmission during this period, as they showed that during two successive years, malaria transmission peaks were observed either in October or at the end of September. In shrubby savanna and steppe villages, the absence of infection as well as the seasonal homogeneous variations in densities could lead to a lower transmission in these villages in comparison to wooded savanna and bare soils villages. However, due to the relatively low number of villages involved (small sample size), these results should be confirmed by more intensive and longitudinal studies.

The study of the influence of climatic parameters on densities showed a non-significant positive correlation of rainfall regardless of the landscape class type. This observation is consistent with that of $\mathrm{Bi}$ et al. [33]. Indeed, An. arabiensis aquatic stages prefer to breed in small, shallow, temporary rain pools or stagnant bodies of water fully exposed to the sun [34]. In our study area, these types of breeding sites are predominant and rainfalldependent as also observed elsewhere [35,36]. A positive but not significant correlation was also observed for humidity while a negative non-significant correlation was observed for temperature. These observations could be due to the relative uniformity of humidity and temperature in the 4 landscape classes. This is further sustained by the fact that, if we consider that water temperature influences the development of aquatic stages of Anopheles species [37], the uniformity of the temperature contributes to similar influences in the different landscape classes.

\section{Conclusions}

Thus, as environmental conditions are closely related to meteorological data, additional studies with a close followup of climatic parameters are needed to ascertain their relationship with entomological parameters. This is reinforced by the fact that climatic parameters can dramatically shift change in mosquito abundance, longevity and infection [38]. From the public health point of view, such information could be useful for human population settlements as well as for monitoring and modelling purposes generating early warning system for implementing interventions.

\section{Additional files}

Additional file 1: Variations of the proportions of An. arabiensis between villages belonging to the same landscape class. For the 
different villages belonging to the same landscape class, means with different letters are significantly different $(p<0.05)$.

Additional file 2: Monthly variations of An. arabiensis and An. coluzzii mean proportions in each of the four landscape classes.

Additional file 3: Correlation between An. arabiensis densities and climatic parameters.

\section{Competing interests}

The authors declare that they have no competing interests.

\section{Authors' contributions}

$I D, Y B$ and $M D$ designed and supervised the study. ID, EMN, NDF, CT, EN, JAN and YB performed field and laboratory activities. ID, EMN, MD analyzed the data and drafted the manuscript. MD and ID revised the manuscript. All authors revised and approved the final version of the manuscript.

\section{Acknowledgments}

We are grateful to Sadio Sow for his technical assistance and help during field investigations and the villagers for their cooperation and their active participation in this study. This study was funded by the EU project QWeCl (Quantifying Weather and Climate Impacts on health in developing countries; funded by the European Commission's Seventh Framework Research Programme under the grant agreement 243964) and the Fonds d'Impulsion de la Recherche Scientifique et Technologique (FIRST) du Ministère de la Recherche de la République du Sénégal.

\section{Author details}

'Unité d'entomologie médicale, Institut Pasteur de Dakar, 36 Avenue Pasteur, BP 220 Dakar, Senegal. ${ }^{2}$ Université Cheikh Anta Diop de Dakar, Dakar, Sénégal. ${ }^{3}$ Université Gaston Berger, Saint-Louis, Sénégal. ${ }^{4}$ Centre de Suivi Ecologique, Dakar, Sénégal.

\section{Received: 5 August 2014 Accepted: 11 December 2014}

\section{2.}

\section{References}

1. Githeko AK, Lindsay SW, Confalonieri UE, Patz JA: Changement climatique et maladies à transmission vectorielle: une analyse régionale. Bull OMS 2000, 78:1136-1147.

2. Bouma MJ, Sondorp HE, Van der Kaay HJ: Health and climate change. Lancet 1994, 343:302.

3. Colwell RR, Epstein PR, Gubler D, Maynard N, McMichael AJ, Patz JA, Sack RB, Shope R: Climate change and human health. Science 1998, 279:968-969.

4. Rogers DJ, Randolph SE, Snow RW, Hay SI: Satellite imagery in the study and forecast of malaria. Nature 2002, 415:710-715.

5. Lindblade KA, Walker ED, Onapa AW, Katungu J, Wilson ML: Land use change alters malaria transmission parameters by modifying temperature in a highland area of Uganda. Trop Med Int Health 2000, 5:263-274.

6. Patz JA, Graczyk TK, Geller N, Vittor AY: Effects of environmental change on emerging parasitic diseases. Int J Parasitol 2000, 30:1395-1405.

7. Lebel T, Diedhiou A, Laurent $\mathrm{H}$ : Seasonal cycle and interannual variability of the Sahelian rainfall at hydrological scales. J Geophys Res 2003, 108:83-89.

8. ljumba JN, Shenton FC, Clarke SE, Mosha FW, Lindsay SW: Irrigated crop production is associated with less malaria than traditional agricultural practices in Tanzania. Trans R Soc Trop Med Hyg 2002, 96:476-480.

9. Keiser J, de Castro MC, Maltese MF, Bos R, Tanner M, Singer BH, Utzinger J: Effect of irrigation and large dams on the burden of malaria on a global and regional scale. Am J Trop Med Hyg 2005, 72:392-406.

10. Mwangangi JM, Shililu J, Muturi EJ, Muriu S, Jacob B, Kabiru EW, Mbogo CM, Githure J, Novak RJ: Anopheles larval abundance and diversity in three rice agro-village complexes Mwea irrigation scheme, central Kenya. Malar J 2010, 9:228.

11. Jacob BG, Muturi E, Halbig P, Mwangangi J, Wanjogu RK, Mpanga E, Funes J, Shililu J, Githure J, Regens JL, Novak RJ: Environmental abundance of Anopheles (Diptera: Culicidae) larval habitats on land cover change sites in Karima Village, Mwea Rice Scheme, Kenya. Am J Trop Med Hyg 2007, 76:73-80.
12. Krefis AC, Schwarz NG, Nkrumah B, Acquah S, Loag W, Oldeland J, Sarpong N, Adu-Sarkodie Y, Ranft U, May J: Spatial analysis of land cover determinants of malaria incidence in the Ashanti Region. Ghana PLoS One 2011, 6:e17905

13. Minakawa N, Sonye G, Mogi M, Yan G: Habitat characteristics of Anopheles gambiae s.s. larvae in a Kenyan highland. Med Vet Entomol 2004, 18:301-305

14. Minakawa N, Munga S, Atieli F, Mushinzimana E, Zhou G, Githeko AK, Yan G: Spatial distribution of anopheline larval habitats in western kenyan highlands: effects of land cover types and topography. Am J Trop Med Hyg 2005, 73:157-165.

15. Fillinger $\mathrm{U}$, Sonye G, Killeen GF, Knols BG, Becker N: The practical importance of permanent and semipermanent habitats for controlling aquatic stages of Anopheles gambiae sensu lato mosquitoes: operational observations from a rural town in western Kenya. Trop Med Int Health 2004, 9:1274-1289.

16. Shililu J, Mbogo C, Ghebremeskel T, Githure J, Novak R: Mosquito larval habitats in a semiarid ecosystem in Eritrea: impact of larval habitat management on Anopheles arabiensis population. Am J Trop Med Hyg 2007, 76:103-110.

17. Lemasson JJ, Fontenille D, Lochouarn L, Dia I, Simard F, Ba K, Diop A, Diatta M, Molez JF: Comparison of bahavior and vector competence of A. gambiae and A. arabiensis (Diptera: Culicidae) in Barkedji, a sahelian area of Senegal. J Med Entomol 1997, 40:396-403.

18. Molez JF, Diop A, Gaye O, Lemasson JJ, Fontenille D: Morbidité palustre à Barkedji, village du Ferlo, en zone sahélienne du Sénégal. Bull Soc Path Ex 2006, 99:187-190

19. FAO: Africover, classification de l'occupation du sol. RSC Series; 1997. 70, 80 pp.

20. Conseil Scientifique pour l'Afrique (CSA): Phytogéographie (Yangambi). Londres: CCTA; 1956:35.

21. Gillies MT, De Meillon B: The Anophelinae of Africa South of the Sahara, 2nd edition. Publ South Afr Ins Med Res 1968, 54:12-36.

22. Fanello C, Santolamazza F, Della Torre A: Simultaneous identification of species and molecular forms of the Anopheles gambiae complex by PCR-RFLP. Med Vet Entomol 2002, 16:461-464.

23. Wirtz RA, Zavala F, Charoenvit Y, Campbell GH, Burkot TR, Schneider I, Esser KM, Beaudoin RL, Andre RG: Comparative testing of monoclonal antibodies against Plasmodium falciparum sporozoites for ELISA development. Bull WHO 1987, 65:39-45.

24. Traoré-Lamizana M, Fontenille D, Diallo M, Bâ Y, Zeller HG, Mondo M, Adam F, Thonon J, Maïga A: Arbovirus surveillance from 1990 to 1995 in the Barkedji area (Ferlo) of Senegal, a possible natural focus of Rift Valley fever virus. J Med Entomol 2001, 38:480-492

25. Traore-Lamizana M, Zeller HG, Mondo M, Hervy JP, Adam F, Digoutte JP: Isolations of West Nile and Bagaza viruses from mosquitoes (Diptera: Culicidae) in central Senegal (Ferlo). J Med Entomol 1994, 31:934-938.

26. Dia I, Diallo D, Duchemin JB, Ba Y, Konate L, Costantini C, Diallo M: Comparisons of human-landing catches and odor-baited entry traps for sampling malaria vectors in Senegal. J Med Entomol 2005, 42:104-109.

27. Dia I, Konate L, Samb B, Sarr JB, Diop A, Rogerie F, Faye M, Riveau G, Remoue F, Diallo M, Fontenille D: Bionomics of malaria vectors and relationship with malaria transmission and epidemiology in three physiographic zones in the Senegal River Basin. Acta Trop 2008, 105:145-153.

28. Konate L, Diop A, Sy N, Faye MN, Deng Y, Izri A, Faye O, Mouchet J: Comeback of A. funestus in Sahelian Senegal. Lancet 2001, 358:336.

29. Lacaux JP, Tourre YM, Vignolles C, Ndione JA, Lafaye M: Classification of ponds from high-spatial resolution remote sensing: application to Rift Valley Fever epidemics in Senegal. J R Sensing Env 2007, 106:66-74.

30. Da DF, Diabate A, Mouline K, Lefèvre T, Awono-Ambene HP, Ouedraogo JB, Dabiré KR: Anopheles rufipes remains a potential malaria vector after the first detection of infected specimens in 1960 in Burkina Faso. J Infect Dis Ther 2013, 1:1-3.

31. Coetzee M, Craig M, le Sueur D: Distribution of African malaria mosquitoes belonging to the Anopheles gambiae complex. Parasitol Today 2000, 16:74-77.

32. el Ngom HM, Ndione JA, Ba Y, Konaté L, Faye O, Diallo M, Dia I: Spatio-temporal analysis of host preferences and feeding patterns of malaria vectors in the sylvo-pastoral area of Senegal: impact of landscape classes. Parasit Vectors 2013, 6:332.

33. Bi $\mathrm{P}$, Tong $\mathrm{S}$, Donald $\mathrm{K}$, Parton $\mathrm{K}, \mathrm{Ni}$ J: Climatic variables and transmission of malaria: a 12-year data analysis in Shuchen County. Chin Publ Health Rep 2003, 118:65. 
34. Gimnig JE, Ombok M, Kamau L, Hawley WA: Characteristics of larval anopheline (Diptera: Culicidae) habitats in Western Kenya. J Med Entomol 2001, 38:282-288.

35. Lindblade KA, Walker ED, Onapa AW, Katungu J, Wilson ML: Highland malaria in Uganda: prospective analysis of an epidemic associated with El Niño. Trans R Soc Trop Med Hyg 1999, 93:480-487.

36. Koenraadt CJM, Githeko AK, Takken W: The effects of rainfall and evapotranspiration on the temporal dynamics of Anopheles gambiae s.s. and Anopheles arabiensis in a Kenyan village. Acta Trop 2004, 90:141-153.

37. Lyimo EO, Takken W, Koella JC: Effect of rearing temperature and larval density on larval survival, age at pupation and adult size of Anopheles gambiae. Entomol Exp Appl 1992, 63:265-271.

38. Bomblies A, Eltahir EA: Assessment of the impact of climate shifts on malaria transmission in the Sahel. Ecohealth 2009, 6:426-437.

doi:10.1186/s12879-014-0711-0

Cite this article as: Ngom et al: Anopheles arabiensis seasonal densities and infection rates in relation to landscape classes and climatic parameters in a Sahelian area of Senegal. BMC Infectious Diseases 2014 14:711.

\section{Submit your next manuscript to BioMed Central and take full advantage of:}

- Convenient online submission

- Thorough peer review

- No space constraints or color figure charges

- Immediate publication on acceptance

- Inclusion in PubMed, CAS, Scopus and Google Scholar

- Research which is freely available for redistribution 